\title{
Green Construction Towards Reducing Energy Consumption and Minimizing the Carbon Dioxide $\left(\mathrm{CO}_{2}\right)$ Emissions
}

\author{
Wail N Al Rifaie* \\ Philadelphia University, Jordan
}

*Corresponding author: Wail N Al Rifaie, Visiting Professor of Civil Engineering, Philadelphia University, Jordan.
Received Date: February 19, 2019

Published Date: March 08, 2019

\section{Opinion}

There are more than 80 developing countries in the world suffering from housing shortage, resulting from population growth. In rural areas, houses should be built as economical as possible and at the same time should be durable and functional. Hence, it has become necessary to seek for structural building elements, which have the structural phenomena of prefabricated elements in terms of ease of handling, light, minimum maintenance and low cost. It is with these in mind, elements of a structural system are made from ferrocement. Ferrocement may be considered as advanced structural materials. It differs from conventional reinforced concrete in that there is a higher ratio of steel to cement mortar. By altering mortar/steel ratio to produce ferrocement which exhibits properties, superior to either steel or cement separately. The influence of heating on the flexural resistance of ferrocement specimens which can be used as pre-cast units or cast in-situ roofing system; chimneys, lining furnaces are carried out. Also, building system must not only cope with strengths and flexibility requirements, but the insulation value is of high importance. Ferrocement has been developed mainly during the past thirty-five years and yet has reached a very advanced stage in technique and design. The low material cost, labor intensity and semi-skilled labor requirements make ferrocement is the most promising alternative materials for housing in rural areas. The constituent materials of ferrocement are easily available and are quite inexpensive. The fabrication technique of ferrocement is quite easy and common people could be trained in a short time to learn the skill.

Ferrocement element, $10-50 \mathrm{~mm}$ thick, is a type of thin reinforced concrete with great potential, made of cement-sand mortar and reinforced with layers of fine wire meshes with skeletal reinforcement. Ferrocement is an excellent construction material due to its mechanical properties, low cost, and it is considered to possess a high cracking strength. The great demands of electric power due to heating and air-conditioning systems require control to make maximum reduction of the electrical energy. Prefabricated ferrocement cavity walls and hollow core slabs/roofs present a series of possibilities for the solution of building construction at maximum reduction of the electrical energy. A structural system (Copyright (C) The University of Nottingham, U.K.) for ferrocement construction based on generic services facilities is introduced. The construction concepts for low cost, low impact housing and shelters lend themselves readily to rapid delivery and assembly of flexible accommodation where designs can be adapted to meet local requirements for both structural performance and thermal comfort. An integral framing concept allows for overall aboveground structural integrity which considerably exceeds that of traditional methods, and this minimizes the need for ground works in all. The membrane construction also enables new concepts in passive downdraught cooling to be explored where airways are incorporated within structural features as wall cavities. Potential applications of the system include sustainable solutions for disaster relief and secure accommodation. The major advantage of a ferrocement construction system over current construction methods is mainly due to the reduction in structural dead load and able to produce very energy efficient dwellings. It is seen that with thermal insulation installed as part of the construction panels lend to achieving high levels of thermal performance. Using (ferrocement eco/green-housing system), the reduction in energy consuming in heating and cooling loads are 50-75\%.

Ferrocement is very adequate to resist the impact, due to its higher ability of absorbing impact energy as compared with the conventional reinforced concrete, and the damage is localized at 
the impact zone. The rehabilitation/strengthening of reinforced concrete element by using ferrocement technique is very effective in increasing the cracking loads, ultimate loads and increasing the impact resistance. In home construction there are two main areas had to be in focus as far as energy assessment: Energy efficiency and Construction efficiency. In fact, energy performance is highly prioritized in the development of building systems and construction productivity. High standards of energy efficient in housing construction have been demonstrated in the modern ferrocement system for green housing. The method is able to produce very energy efficient dwellings. It is seen that with thermal insulation installed as part of the construction panels lend to achieving high levels of thermal performance, consequently, a reduction in emission of $\mathrm{CO}_{2}$.

The ferrocement building components can withstand direct fire with a temperature values up to $756^{\circ} \mathrm{C}$ for a period of $2 \frac{1}{2}$ hours with no segregation in the surface of the elements facing the fire. A research work to examine the mechanical properties of Nano particles in developing a cement mortar which can lead to improvements in the performance of ferrocement as structural elements in the structural system for green housing was carried out. The flexural strength value of Nano ferrocement prism having $10 \mathrm{~mm}$ thickness with 6-layers of wire mesh is higher than that of normal ferrocement prism having $22 \mathrm{~mm}$ thickness with 6-layers of same wire mesh. A very thin structural element called nanopolymercement composite was developed. The element may be used for example, strengthening or rehabilitation of pipe lines for pressurized pipes, construct poles for lighting and wind turbine, water tanks, and anti-bullet protective panels. Expression for determining the modulus of elasticity was formed.

\section{Acknowledgment}

None.

\section{Conflict of Interest}

No conflict of interest. 